\title{
Muş'ta Yabani Bitkilerin Halk Hekimliğinde Kullanılması*
}

\author{
Usage of Savage Plants in the Folk Medicine in Muş \\ Canser Kardaşi
}

' Dr. Öğr. Üyesi, Muş Alparslan Üniversitesi, Fen Edebiyat Fakültesi, Türk Dili Ve Edebiyatı Bölümü, Türk Halk Bilimi AD https://orcid.org/0000-0001-8557-8706

\section{öz}

Halkbilgisinin önemli bir şubesi kabul edilen halk hekimliği, yaşayan halkbilimi unsurları arasında varlığını devam ettiren en önemli alandır. Modern tıbbın temelini oluşturan halk hekimliğinin, sosyo-ekonomik durum ve inanç gibi nedenler başta olmak üzere farklı sebeplerle günlük hayattaki uygulamaları devam etmektedir. Halk hekimliğinde ilaç olarak kullanılan ana unsurlardan biri, yabani bitkilerdir. Binlerce yıllık tecrübeler sonucunda oluşan uygulamalar, modern tıp çok gelişmesine rağmen önemini yitirmemiş, aksine alternatif tıp, tamamlayıcı tıp gibi isimler alarak varlığını devam ettirmiştir. Halk hekimliği, bulunduğu toplumun kültürel özelliklerini de yansıtmaktadır. Günümüzde halk hekimliğinin bitkilerle yapılan tedaviye olan güvenin güçlü olmasından ötürü esas itibariyle yararı olmasa da vücuda büyük zararı olmayacağına inanılmaktadır.

Çalışmada Muş'un bitki örtüsüne bağlı olarak yetişen çeşitli yabani bitkilerin ve bu bitkilerin halk hekimliğindeki kullanım şekilleri, yerel isimleri ve kullanım amaçlarının tespit edilip kültürel etkinlik olarak kayıt altına alınmassı amaçlandı. Çalışmanın materyali Muş ve çevresinde seçilen kaynak kişilerle yüz yüze görüşme yoluyla elde dilen bilgilerdir.

Çalışmada Muş ve çevresinde halk hekimliğinde kullanılan bir kısım yabani bitkilerin inanç bazında veya telkin yoluyla; bir kısım yabani bitkilerin de tecrübe yoluyla iyileştirici özelliği tespit edildiği anlaşıldı. Yine bazı bitkilerin birden fazla hastalık için bazılarının ise sadece bir hastalığın sağaltmasında kullanıldığı tespit edilmiştir.

Sonuç itibariyle halk arasında doğada kendi kendine yetişen bitkilerin her türlü hastalık için deva olduğu inancının varlığı ve buna bağlı olarak yörede yetişen her bitkinin bir hastalığın sağaltmasında kullanıldığı anlaşılmıştır.

Anahtar Sözcükler: Muş, halk hekimliği, yabani bitkiler.

\section{ABSTRACT}

Folk medicine, which is regarded as an important branch of folk knowledge, stands as the most important surviving field among living folklore elements. Folk medicine which constitutes the basis of modern medicine, continues to be applied in daily life for various reasons particularly the socio-economic status and beliefs. One of the main elements used as medicine in folk medicine is wild plants. Practices based on experiences of thousand years have not lost their importance despite the developments in modern medicine, yet have continued to exist under the name of alternative medicine or complementary medicine. Today because of the strong trust in treatment of plants, it is believed that folk medicine does not harm the body even if it does not heal.

The study aims to determine what the local names of the wild plants growing within the vegetation special to Muş are, why and how they are used as folk medicine and to record those as cultural activities. Material of the study is the information gotten through face to face interviews conducted with people related to the subject across Mus.

The study indicated that some of the wild plants used as folk medicine heal because of beliefs or by persuading while some other heal due to former experiences. Besides it was determined that while some plants are used to treat one particular disease, some others are used to heal several diseases.

In conclusion, people believe that plants growing themselves in nature heal all diseases and hence each plant gowing in a certain area is used to treat a particular disease.

Key Words: Muş, folk medicine, savage plants

*Lokman Hekim Dergisi, 2019; 9 (1):85-96

DOI:10.31020/mutftd.468848

e-ISSN: $1309-8004$

Geliş Tarihi - Received: 10 Ekim 2018; Kabul Tarihi - Accepted: 18 Aralık 2018

Iletişim - Correspondence Author: Canser Kardaş <kardascanser@gmail.com> 


\section{Giriş}

İnsanlar için yeme, içme, barınma vb. zorunlu ihtiyaçlarının yanında, sağlığını koruma ya da hastalıktan kurtularak yaşamlarını devam ettirebilmek önem taşımaktadır. Illk çağlardan beri insanlar yaşadıkları bölgelerin özelliklerine göre kültürler oluşturmuştur. ${ }^{1}$ Kültür, insanların yaşadıkları bölgenin coğrafi yapısı, iklimi, bitki örtüsü, suya yakınlık durumuna göre diğer bir ifadeyle doğanın zorlayıcı etkisiyle şekillenmiş ve şekillenmeye devam etmektedir. Doğanın sunduğu imkânlara göre hayvancılığa veya tarıma yönelme, giyim-kuşam, yerleşme tipi şekillenmektedir. Bu açıdan bakıldığından sadece doğa insanı etkilememiş aynı derecede insan da doğayı kendi intiyaçlarına göre şekillendirmeyi başarmıştır. Sosyal sistemlerin temel fonksiyonlarından birinin toplumların çevreye adaptasyonu olduğunu belirten Çopuroğlu, insanın diğer canlılardan farklı olarak fizyolojik mutasyonla değil, kültürel adaptasyonla karşı koyarak çevreye uyum sağladığını belirtmektedir. ${ }^{2}$ Doğanın şartları ne kadar zor olursa olsun insanlar bulundukları bölgelerin özelliklerine göre doğaya adapte olmaktadırlar. Halk hekimliğinde bölgelerarası pek çok farklılık olmasının yanında, bitkisel, hayvansal, madeni ve sihir-büyüye dayalı benzer uygulamalar da bulunmaktadır. ${ }^{3-6}$

Türkiye'de yirminci yüzyılın üçüncü çeyreğinden sonra yaşanan hızlı toplumsal değişimler, tıp biliminin hızla ilerlemesi, köyden kente yoğun göç binlerce yıllık birikimin ürünü olan halk hekimliği uygulama ve tedavilerine rağbeti azaltmıştır. Ancak son yıllarda özellikle alternatif tıp veya tamamlayıcı tıp gibi adlar altında, özellikle bitkisel ilaçlar ön plana çıkarılmak suretiyle halk hekimliği yeniden gözde bir hale getirilmektedir. Sağlık Bakanlığının da hacamat ve sülük tedavisi başta olmak üzere geleneksel halk hekimliği uygulamalarına sıcak bakması ve bunu yönetmeliklerle desteklemesi, halk hekimliğinin halk arasında yeniden yayılmasını sağlamaktadır. ${ }^{7}$

Ülkemizde halk hekimliği ile ilgili yapılan tez çalışmaları, başta halkbilimi olmak üzere eczacılık, tıp, hemşirelik, veterinerlik, zooloji ve antropoloji alanlarında yoğunluk kazanmaktadır. ${ }^{8}$ Son dönemlerde halk hekimliğinde kullanılan bitkilerle ilgili incelemeler, "Bir yörede yaşayan halkın yakın çevresinde bulunan bitkilerden çeşitli gereksinimlerini karşılamak üzere yararlanma bilgisi ve o bitkiler üzerine etkileri inceleyen" kısaca "insanlarla bitkiler arasındaki ilişkiyi inceleyen bilim dalı" olan etnobotanik alanında da yoğunluk kazanmıştır. ${ }^{9,10}$

Yeni ilaç hammaddesi araştırmalarında önemli bilgi kaynaklarından biri kabul edilen geleneksel ilaçların ${ }^{3}$ tespiti, yapımı, kullanım şekli ve saklama koşulların belirlenmesi hem halk bilimi açısından hem de tıp, eczacılık, hemşirelik ve veterinerlik gibi sağlık bilimlerinin tamamı için önemli katkılar sunmaktadır. Uygulamalar tamamen geleneksel yöntemlere dayanmasına rağmen, kimi bitkilerin doğrudan yaraların tedavisinde kullanılması ve bazı hastalıkların iyileştirici etkisiyle karşılaşmaları bu tedavi yönteminden haberdar olan halk sayesinde bitkilerin sağlık üzerine etkisinin kısa sürede geniş bir coğrafyaya ulaşmasını ve böylece uygulamanın geniş bir alana yayılmasını sağlamaktadır.

Muş'un bulunduğu coğrafya, kışları çok sert ve yağışlı geçtiğinden bahar aylarında bitki örtüsü binlerce ot çeşidine ev sahipliği yapmaktadır. Yörede yaşayan insanlar, bu bitki örtüsüyle o kadar hemhal olmuşlar ki yağış miktarına göre yenilen veya ilaç olarak kullanılacak bitkinin hangi yükseltide bulacağını çok iyi bilmektedir. Yine yağış miktarını ve yağış dönemini göz önünde bulundurarak bitkinin erken veya geç yetişmesini kolaylıkla kestirebilmektedirler. Çoğu zaman "Bu yıl Muş'ta cağ olmayacak" dediklerinde kar az yağmıştır, ya da "Artık bu yıl mantarı Karlıova tarafından getiririz" dediklerinde yağmurun az yağdığı anlaşılmaktadır. Tersi durumda ise "Bu yıl Muş’un "Gulik”ı tüm Türkiye’ye yeter." denildiğinde bol yağışı bir yıl geçirilmiştir. Görüldüğü gibi Muş halkı, şehrin iklimi ve doğası ile bütünleşen bir kültür oluşturmuşlardır (KK1-KK16). 
Çalışmamız, çevrede halk hekimliğinde uzmanlaşmış kişilerden ziyade sıradan kişiler seçilerek yapılmıştır. Bu kişiler halk hekimliği konusunda çok derin bilgiye sahip olmamalarına rağmen, derin tıbbi bilgiye ihtiyaç duyulmadan basit tedavileri yapabileceklerine olan inançtan dolayı, bilgiler aileden veya çevreden öğrenilmektedir (KK1-KK16).

İmkânların kısıtlı olduğu veya özel gerekçelerle medikal tıpa başvurulamadığı durumlarda, hastalıkların geleneksel yöntemlerle teşhisi ve tedavisi amacıyla yapılan tüm uygulamalara halk hekimliği denilmektedir. Uluslararası yazında "folk medicine", Türk yazınında da "geleneksel tıp" olarak bilinmektedir. "Geleneksel tıp", "halk tababeti", "folklorik tıp", "alternatif tıp" ve "tamamlayıcı tıp" gibi adlar verilen halk hekimliği günümüzde yeniden rağbet görmeye başlamıştır. Binlerce yıllık bilgi birikimi sonucunda oluşan halk hekimliğinde Boratav, sağlatma yöntemlerini büyülük ve büyülük ile akıllılık birbirini tamamlayan yöntemler olarak ikiye ayırmıştır. ${ }^{4}$ Baytop, halk tababetinin bitkilerle tedavisi bir kültür ve geleneğe bağlı olduğu dolayısıyla tarihi kimliğe sahip kentlerde daha yaygın olduğunu belirtmektedir. ${ }^{12}$

Günümüzde yapılan pek çok araştırmada, hastalıkların tedavisinin çift yönlü olarak yapıldığı anlaşılmaktadır. ${ }^{13}$ Tedavi için, modern tıpa yönelmişse geleneksel tedavinin de ihmal edilmediği veya geleneksel tedaviye yönelmişse modern tıpa da başvurulduğu görülmektedir. Biyolojik kaynaklı bir hastalık kişileri daha çok modern tıpa yönlendirirken doğaüstü kaynaklı olduğu düşünülen hastalıklar ise geleneksel tedavi uygulayan hekimlere yönlendirmektedir. Her iki durumda da birinde istenilen iyileşme sağlanamamışsa diğerine başvurulmaktadır.

Sever, geleneksel halk hekimliğinin insanların tabiat olayları, çevrelerini algılama, anlamlandırma ve etkisinde kaldıkları olay ve durumlara karşı tepkide bulunma ve toplumsal yaşam içindeki sonucu doğduğunu belirtmektedir. ${ }^{5}$ Kaplan ise sağlık ve hastalığa ilişkin bilgi ve uygulamaların kuşaktan kuşağa aktarılmasıyla oluşan, her aktarımıyla birlikte aynı zamanda yeniden üretilen "sözlü" sağlık bilgisii ${ }^{14}$ şeklinde açıklayarak, halk hekimliğinin de uygulamaya dayalı olsa dahi aslında sözlü kültür ürünlerinin aktarımı üzerine kurulduğunu vurgulamaktadır.

Yoder, bir zamanlar akademik tıp olarak değerlendirilen pek çok uygulamanın veya reçetenin günümüzde halk tıbbı olarak değerlendirildiğini belirterek, günümüzde halk tıbbına sadece köylü veya ekonomik durum bakımdan iyi olmayanlar değil, aksine elit olarak kabul edilen veya ekonomik durumu iyi olanların da başvurduğunu belirtmektedir. ${ }^{12}$ Yoder, halk tıbbını "Tabii halk tıbbı ve dinsel-büyüsel halk tıbbı" olarak ikiye ayırmakta ve halk tıbbını da "Halk arasında görülen hastalıklara karşı uygulanan iyileştirme metotlarının tümü ile hastalıklar üzerine olan geleneksel görüşlerin bütünü" şeklinde tanımlamaktadır. ${ }^{15}$ Yoder'in yaklaşımı halk hekimliğinin farklı dönemlerin modern uygulamaları iken zamanla daha modern uygulamaların çıkmasıyla bilimin terk ettiği yöntemler olduğunu dolayısıyla halk arasında gelişen doğal sağaltım şekilleri olarak değerlendirmediğini anlaşılmaktadır. Bizce tüm halk hekimliğinin bu şekilde değerlendirilemeyeceği kimi uygulamalar, bilimin terk ettiği yöntemler olsa da halkın kültürel sınırlar çerçevesinde oluşturduğu sağaltma şekilleri olduğu şeklindedir.

Hastalık tedavi yöntemlerinin insanlık tarihi ile başladığı kolaylıkla söylenebilir. Hastalıklara karşı deneme yanılma yoluyla veya usta çırak ilişkisi ile biriken bilgi, sözlü kültür aracılığıyla sonraki kuşaklara aktarılmıştır. Anadolu'da halk hekimliği ile ilgili yazılı bilgiler, bitkilerle tedavi yöntemlerini Hititlere (MÖ 1500) kadar götürülmektedir. ${ }^{12,16}$ Toplumların göçlerle sürekli yer değişiklikleri sonucunda karma kültürler oluşmuş, aynı şekilde geleneksel tedavi yöntemleri de bu yönlü çeşitlenerek yeniden üretim biçimi süreklilik kazanarak kuşaklar boyu devam etmiştir.

Halk hekimliğinde kullanılan ilaçlar bitkisel, madeni veya hayvansal olabilmektedir. Halk arasında kullanılan ve geleneksel yöntemlerle üretilen ilaçlara "ev ilaçları" ya da "kocakarı ilaçları" denilmektedir. Halk arasında 
kullanılan "kocakarı ilaçları" ifadesi olumsuz anlam ${ }^{18}$ taşımakta kısmen de küçümsenmektedir. Bu ifade, halk hekimlerine giden kişilerin cahillikle suçlanmalarına yol açtığından, modern tıptan umudunu kesenlerin veya tamamen ekonomik yetersizliğe sahip kişilerin ziyaret ettiği kişilerle özdeşleşmiştir. Boratav, "kocakarı ilaçları"nın eski tıbbın bugün için eskimiş ve uygulanmaz olmuş sağaltma ve ilaçlar olduğunu belirtmektedir. ${ }^{4}$ Yapılan gözlem ve görüşmelerden, günümüz toplumlarında bu algının yavaş yavaş değiştiği ve beklenmedik derecede "kocakarı" ilaçlarına talebin arttığı anlaşılmaktadır.

Halkın hastalıklar ve hastalıkların tedavilerine yönelik geliştirilen yöntemler, yaşanılan bölgenin coğrafi yapısı, iklimi ve kültürel unsurlarından etkilenmektedir. Hastalığa karşı önlem alma, hastalığın teşhisi ve tedavi şekli üzerinde yine kültürel yapı ve iklim başta olmak üzere inançlar da etkili olmaktadır. Kaplan, toplumların kendilerine özgü hastalık işaretlerine, belirtilerine, tanımlamalarına ve sağaltmalarına sahip olduğunu belirtmektedir. ${ }^{14}$ Bu kapsamda bakıldığında Muş'ta hastalıkların adlandırılmasında, belirtilerin fark edilmesinde ve sağaltılmasında büyük oranda özgün özellikler geliştirilmiştir.

Halk hekimliğinde hastalıkların tedavisi ırvasalama, parpılama, kırık-çıkık ve em şeklinde görülmektedir. ${ }^{6}$ Muş ve çevresinde sözü edilen dört şekilde de sağaltma uygulamaları görülmektedir. Makalede sadece em içinde değerlendirilen bitkilerden elde edilen tedavi şekilleri değerlendirilecektir.

Çalışmamız, genel olarak halkın doğada kendiliğinden yetişen yabani bitkilerin tedavide kullanım şekli ve bilgisinin tespiti üzerinedir. Tespit edilen bitkiler ve kullanıldıkları tedavi şekilleri sadece folklor yönüyle değerlendirilmiştir. Folklor bilgisinin derlenmesi ve değerlendirilmesi temel amaç olarak belirlenmiştir. Çalışmamızda herhangi bir sağıı dalı dikkate alınarak bir laboratuvar çalışması yapılmamış olup, doğru veya yanlış yönden değerlendirilmeden, yabani bitkilerin tamamen halk arasında bilinen şekilleri dikkate alınmıştır.

\section{MATERYAL VE METOT}

Muş'un sert karasal ikliminin etkisiyle soğuk havalardan kaynaklı enfeksiyon hastalıklarının yaygın olduğu bir bölgedir. Bunun neticesi olarak halk, hastalıklara karşı farklı sağaltma yöntemleri geliştirmiştir. Bu sağaltma yöntemleri, farklı ot çeşitlerinin hem yemek hem de çay olarak tüketilmesi şeklinde gerçekleşmektedir. Türkiye florasında yaklaşık 8500 tür bulunduğunu belirten Baytop, bunlarda sadece 650 ismin belirlenebildiğini bildirmektedir. ${ }^{12}$ Türkiye'de yıllardır bu çalışmalar yapıldığı halde henüz yabani bitkilerin elde sağlam bir listesi oluşmamıştır. ${ }^{17}$ Sağlam bir bitki listesinin oluşturulması; bitki coğrafyasının, halk hekimliğinde kullanımının ve halk kültüründeki yerinin tespiti ile mümkün olacaktır. Kaynak kişiler (KK-) ve tablo şeklinde (Tablo 1) verilmiştir. Bitkilerin yerel adları (Çoğunlukla Kürtçe), Türkçe ve Latince karşılıkları da eklenerek tablo şeklinde (Tablo 2) gösterilerek bitkilerin tanınırlığı artırılmaya çalışımıştır. ${ }^{19,21}$ Çalışmada bitki adları Muş’ta kullanıldığı şekliyle yazımıza alınmıştır. Buna göre bitki adları da bu kullanılıs esas alınarak hem tabloda hem de açıklamalarda alfabetik olarak sıralanmıştır. Bitki adlarının Türkçe ve Latince karşılıkları sözlüklerden tespit edilmiştir. ${ }^{17,19}$ Ayrıca bulgular kısmında yer alan bitkilerin halk hekimliğinde kullanım şekilleri ile ilgili açıklamalar kaynak kişilerin ifadelerine müdahale edilmeden olduğu gibi aktarılmıştır.

Çalışmanın materyalleri 14.03.2018 ve 15.09.2018 tarihleri arasında Muş ve çevresinde rastgele seçilmiş farklı yerleşim birimlerinden ve farklı yaş gruplarından olmak üzere toplam 16 kaynak kişi ile yapılan görüşmeler sonucunda veriler elde edilmiştir. Görüşme yapılan kaynak kişiler halk hekimi olmayıp genel olarak kırsalda halk hekimliği konusunda herkesin sahip olduğu bilgilerdir. Kaynak kişilerle yapılan görüşmelerde elde edilecek veriler ile kimlik bilgilerinin bilimsel çalışmalarda kullanılacağı izni sözlü olarak alınmıştır. 
Tablo1. Kaynak Kişiler

\begin{tabular}{|c|c|c|c|c|c|}
\hline Kaynak Kişi No & Adı Soyadı & Mesleği & Yaş & Görüşme yeri & Görüşme Tarihi \\
\hline KK1 & M.G. & Çiftçi & 72 & Zivzer Muş & 10.04 .2018 \\
\hline КК2 & A. U. & Ev hanımı & 67 & Yeroluk Muş & 18.06 .2018 \\
\hline ККЗ & F. U. & Ev hanımı & 58 & Muş Merkez & 11.05 .2018 \\
\hline КK4 & Z. U. & Ev hanımı & 65 & Suvaran Muş & 11.05 .2018 \\
\hline KK5 & E. T. & Çalışmıyor & 25 & Suvaran Muş & 11.05 .2018 \\
\hline КK6 & M. G. & Ev hanımı & 45 & Muş Merkez & 14.03 .2018 \\
\hline KK7 & H. A. & Ev Hanımı & 50 & Muş Merkez & 14.03 .2018 \\
\hline KK8 & Z. Ö. & Ev Hanımı & 43 & Muş Merkez & 16.04 .2018 \\
\hline КK9 & R. Ç. & Serbest & 55 & Muş merkez & 16.04 .2018 \\
\hline Кк10 & C. T. & Ev Hanımı & 68 & $\begin{array}{l}\text { Konukbekler [Anzar] } \\
\text { Muş }\end{array}$ & 22.03 .2018 \\
\hline КК11 & R.T. & Serbest & 58 & Muş Merkez & 21.08 .2018 \\
\hline КK12 & M. Ş. A. & Çalışan & 37 & Muş Merkez & 04.09 .2018 \\
\hline КК13 & Y. K. & Ev Hanımı & 55 & Bulanık Muş & 06.09 .2018 \\
\hline КК14 & H. M. & Emekli & 70 & Malazgirt Muş & 11.09 .2018 \\
\hline КК15 & A. T. & Emekli & 85 & Varto Muş & 15.09 .2018 \\
\hline KK16 & R. Ö. & Emekli & 82 & Bulanık Muş & 10.09 .2018 \\
\hline
\end{tabular}

\section{BULGULAR}

Muş ve çevresinde tespit edebildiğimiz ve halk hekimliğinde kullanılan bitkiler Tablo 2'de gösterilmiştir.

Cağ (Çakşır): Şeker hastalığına iyi geldiği gibi, kısırlık önleyici aynı zamanda kas ve vücut direncini artırıcı özelliğe sahiptir. (KK-5; KK-8; KK-9; KK-14). Bu otun çok tüketilmesi ile alakalı Varto'nun Kaynarca köyünde yaklaşık yüz ikizin olması ile ilgi kurulmaktadır. ${ }^{20}$ ikizlerin varlığından dolayı halk arasında "ikiziksiri" otu olarak da bilinmektedir. Çevrede halk arasında "Cağ hem ikiz yapar hem de çocuğu olmayana çocuk verir" ifadesi yaygındır.

Cehtirî (Dağ kekiği): Üzerine kaynar su bırakılıp bir süre bekledikten sonra içildiğinde soğuk algınlığına, öksürüğe ve astıma yararlıdır. (KK-3; KK-5). Çay şeklinde tüketilirse nefes darlığını azaltır (KK-14).

Encuz: Bal ile karıştırılarak yenilirse basura iyi gelmektedir (KK-8; KK-9).

Gezgezk (Isırgan otu): Çiğ olarak saç dökülmesine karşı kullanılmaktadır. Ayrıca mide yaraları ve kanser için iyidir (KK-3; KK-4; KK-5). Kanser hastaları başta olmak üzere tüm kan hastalıklarına çorbası iyi gelmektedir (KK-1; KK-6; KK-7; KK-13). Ancak kanser hastaları suyunu içmemelidir Haşlanıp suyu içilirse sivilceler için de şifalıdır. (KK-8; KK-9). Aybaşı düzensizliğine ve sancılara iyi gelir. Romatizmalı bölgelere çiğ olarak bırakılırsa ağrı yatıştırıcı özelliği vardır. Kaynatılıp suyu içilirse mide, iltihaba ve sarılığa da iyi gelmektedir (KK-2; KK-8; KK-9). Mide kanamalarında yararlı bir bitkidir (KK-14). 
Tablo2. Muş'ta Halk Hekimliğinde kullanılan Yabani Bitkiler

\begin{tabular}{|c|c|c|c|}
\hline S.No & Kürtçe adı & Türkçe adı & Latince adı \\
\hline 1 & Cağ & Çakşır-Kasnı & Ferula rigidula \\
\hline 2 & Çehtirî & Dağ Kekiği & Thymbra sintenisii \\
\hline 3 & Gezgezok-Gezgezg & Isırgan otu & Urtica dioica \\
\hline 4 & Givîj & Alıç & Crataegus orientalis \\
\hline 5 & Gizer & Yabani havuç & Daucus carota \\
\hline 6 & Gulik, Gulbahar & Çiriş otu & Eremurus spectabilis \\
\hline 7 & Guriz & Sığırdili & Anchusa oficinalis \\
\hline 8 & Gurnîk & Pitrak & Xanthium \\
\hline 9 & Helin Dilan & Dar yapraklı sinirli ot & Plantago lanceolata \\
\hline 10 & Heliz & Çakşır otu & Ferula szowitsiana \\
\hline 11 & Helizerk & Üzerlik & Peganum harmala $L$. \\
\hline 12 & Hîro & Hatmi çiçeği & Alcea \\
\hline 13 & Karî-Karik-Kardî & Yılanyastığı & Arum elognatum STEVEN subsp. Elongatum \\
\hline 14 & Kereng & Kenger & Gundelia tournefortii \\
\hline 15 & Kersım & Dağ teresi & Lepidium \\
\hline 16 & Kuşkonmaz & Melajo & Asparagus officinalis \\
\hline 17 & Mendik-Mendo & $\begin{array}{l}\text { Orman maydanozu-Frenk } \\
\text { maydanozu }\end{array}$ & Chaerophyllum bulbosum \\
\hline 18 & Nanê Çivik & Çobançantası & Capsella bursa-pastoris \\
\hline 19 & Parpar & Semizotu & Portulaca oleracea \\
\hline 20 & Pêjek-Hiso-Soo & Öğrek otu & Heracleum persicum \\
\hline 21 & Pelhewêz-Berghevez & Geniş yapraklı sinirli ot & Plantago majör \\
\hline 22 & Piltan & Civanperçemi & Achillea biebersteinii \\
\hline 23 & Pung & Yarpuz & Mentha pulegium \\
\hline 24 & Qanok & Karakavuk & Chondrilla juncea \\
\hline 25 & Ribes & Işkın & Arheum ribes \\
\hline 26 & Sipînk & Yemlik & Tragopagon \\
\hline 27 & Sîrim & Yayla sarımsağı & Allium arlgirdense \\
\hline 28 & Soryaz & Doğu soğanı & Allium orientale \\
\hline 29 & Spîdak-Serbışk & Tükürük otu & Ornithogalum wiedemannii \\
\hline 30 & Sus & Meyan otu & Glycyrrhiza glabra \\
\hline 31 & Şelepuk & Papatya & Matricaria chamomilla \\
\hline 32 & Şilan & Kuşburnu & Rosa canina \\
\hline 33 & Tirşok & Kuzukulağı & Rumex tuberosus \\
\hline 34 & Tolik & Ebegümeci & Malva neglecta \\
\hline 35 & Xuşîr- xaleşîrk & Süt otu, sütlüce & Euphorbia blue peaks \\
\hline
\end{tabular}


Givîj (Alıç): Romatizmaya iyi gelmektedir (KK-3; KK-4; KK-5). Beyazı kalp hastalıkları için iyidir (KK-9). Çiçeklenme mevsiminde çiçekleri toplanıp kurutulursa, çayı şeker hastalı̆̆ında kullanılabilir. (KK-8; KK-9). Meyvesi taze tüketilirse kabızıı için de yararlıdır (KK-10). Kırmızı ve yumuşak olan cinsinden yenilirse kabızlığı giderir (KK-12).

Gizer (Yabani havuç): Görme düşüklüğünde gözün ışığını artırır (KK-13).

Gulik-Gulbahar (Çiriş otu): Bağırsakları çalıştırarak sindirimi hızlandıır (KK-1; KK-3; KK-4; KK-5; KK-12; KK13). Bademcik, bağırsaklar ve vücudun herhangi bir yerindeki iltihaba iyi gelmektedir (KK-8; KK-9). Bağırsakları ve idrar yolunu temizler (KK-11). Kabızlığı giderir (KK-13).

Gulik o kadar seviliyor ki onunla ilgili efsaneler de oluşmuştur. Muşa bir gün bir lokman hekim gelir, caddelerde marketlerde birçok yerde gulik satıldı̆ıını görür. Herkesin bunu tükettiğini görünce, Muş halkının kolay hastalanacağını muhtemelen pek çok hastalığın da yaygın olduğunu söyler. Bana çok büyük iş düşer diye aklında geçirir. Gulik otunun yetiştiği yerleri merak eder ve Muş'un hemen güneyinde yer alan Kurtik dağına çıkar. Orada da ışkın görür ve "Muş halkı gulikten hastalanır ışkından iyileşir." dedikten sonra Muş'tan ayrılmaya karar verir (KK-8). ${ }^{23}$

Gumuş: İ̧̧tah açıcıdır (KK-3; KK-5). Arı sokmalarında iğnenin batııılığı yere bastırılırsa zehri dışarı çeker (KK8; KK-9).

Guriz (Sığırdili): Romatizmaya ve mide ağrılarına iyi gelmektedir (KK-3; KK-4; KK-5; KK10). Bağırsaklara yararlı olup, açık yaraları iyileştirici özelliği vardır. Dolayısıyla açık yaralar için tereyağında krem haline gelinceye kadar kaynatılır. Elde edilen krem açık yaraya sürülür (KK-8; KK-9). Genel olarak kadın hastalıklarına yararlı olan bir bitkidir (KK-11). İyice haşlandıktan sonra bir bezin içine sararak epilepsi hastalarının başına bırakılırsa, dinlendirici özelliği vardır (KK-1).

Gurnik (Pıtrak): Çocuğu olmayan kadınlar için yararlıdır (KK-8; KK-9).

Helin-Dilan (Dar yapraklı sinirli ot): Bu ot kurutularak çay şeklinde tüketilirse iç organlardaki iltihaba iyi gelmektedir (KK-7; KK-11)

Heliz (Çakşır otu): Şeker hastalığına iyi gelir. Ayrıca kurutularak sabun yerine de kullanılmaktadır (KK-6; KK7; KK-8; KK-9). Kalp hastalıklarına ve nefes darlığına iyi gelmektedir (KK-10).

Helizerk (Üzerlik): Ağrı kesici özelliğinin yanında kurt da düşürür. Ayrıca tohumları kurutulduktan sonra çeşitli şekillere sokularak nazar için de kullanılmaktadır (KK-16; KK-11).

Hîro (Hatmi): Çayı diz ağrılarını dindirir (KK-13). Yılan sokmalarında bitkinin sapları, çiçeği ve yaprakları bir dibekte hamurlaşıncaya kadar dövülür. Daha sonra ayrana karıştırılarak yılanın soktuğu bölgeye yedi gün boyunca bu karışım, bezin üzerine bırakılarak sarılır. Karışım zehirli sarı suları yavaş yavaş dışarıya akıtır. Ayrıca bitki iyice dövüldükten sonra ayrana karıştırılarak içilse öksürüğü de keser (KK-15). Eskiden fakirlik döneminde sabun bulunmadığından ölülerin yıkanacağı suyun içine konulurdu. Otun köpürme özelliği sayesinde ölüler daha rahat yıkanırdı (KK-16)

Kari-Kardî (Yılanyastığı): Dut pekmezi ile karıştırılarak sürülürse kadın memelerinde oluşan yaraları ve şişkinliği giderir (KK-1). Bağırsaklarda oluşan kurtların düşürülmesinde faydası vardır (KK-3; KK-4; KK-5). Doğum yapan kadınların sancılarının yatışması için kaynatılıp suyu içilir. Ayrıca tüm iç hastalıklar için iyidir (KK-2). Kadınlarda sancı ve baş ağrısı için kaynatıldıktan sonra suyu iyi gelmektedir (KK-8; KK-9). Su, soğan ve yağla pişirildiğinde lohusa kadınlar için iyidir (KK-6; KK-7; K11). Vücudun zayıf düşmesini engellemektedir (KK-13). 
"Kari" çoğunlukla kadın hastalıklarında kullanılageldiğinden, otun kızların çeyizlerinde bulundurulması bir gelenek halini almıştır. Ancak sonradan çeyizde bu ota yer verme geleneği bırakılmış olup, daha çok gelin ziyaretinde "Kari" götürülmeye başlanmıştır. Günümüzde ise bu geleneği yaşlılar dışında hatırlayanlar bulunmamaktadır. Bu otun hediye olarak götürülmesi veya çeyizde bulundurması kişiden ailenin/soyun devamı için çocuk beklenildiğini ve bunun için gerekli hazırlıkların yapılması uyarısını da barındırmaktadır (KK-10). Bu otu bazı aşiretler toplamaz. Örneğin Elmani Aşireti mensubu bir kişi bu otu toplarsa aile bireylerinde birinin ağır bir hastalığa yakalanacağına inanılır (KK-5).

Kereng (Kenger): Şeker hastalığına iyi gelir (KK-3; KK-4; KK-5). Mideye yararlı bir bitkidir (KK-11). Aç karınla yenilmesi durumunda ağız kokusunu giderir ve nefesi açma özelliği vardır (KK-1). Taze olarak tüketilirse diş ağrısını yatıştııır (KK-13).

Kersim (Dağ teresi): Nefes darlığına iyi gelir (KK-8; KK-9).

Malîvaş: Bağırsak kurtlarını Düşürür (KK1)

Melajo (Kuşkonmaz): Sindirimi kolaylaştırır. Kanser riskini azaltır ve bağışıklık sistemini güçlendirir (KK-10).

Mendo (Orman Maydanozu): Karın ağrısı dindirir (KK-8; KK-11).

Nane çıvik (Çobançantası): Çiğ olarak veya pişirilerek yenilirse iltihap kurutur (KK-3; KK-5; KK-8; KK-9).

Parpar (Semizotu): Bağırsakları çalıştırarak temizlenmesini sağlar. Ayrıca bel ağrısına da iyi gelmektedir (KK8; KK-9-K11). Haşlanarak yenilirse, kanser hastalıklarına yararı bulunmaktadır (KK-12).

Pejek-hiso-soo (Öğrek Otu): Çocukların karın ağrısına iyi gelir. Çocuk ve bebeklerin karın şişliğinde üzerine bırakılırsa rahatlatır (KK-8; KK-9). Ayrıca baş ağrılarını yatıştırmak için kaynatılıp suyu içilirse rahatlatıcı özelliği bulunmaktadır (KK-6; KK-7). Yemeği ve suyu kanser hastalarına yararlıdır (KK-12).

Pelhewêz-Bergheves (Geniş yapraklı sinirli ot): Illtihaplı yaralarda iltihap kurutucu özelliği vardır (KK-3; KK-4; KK11). Açık vücut yaraları başta olmak üzere basur ve mantarların tedavisine de iyi gelmektedir (KK-2). Kaynatılıp suyu içilirse mideye yararlıdır (KK-6; KK-7). İltihaplanmış dişlerin iltihabının sökülmesi için iyidir. İltihaplanmış dişin eti üzerine bırakılır birkaç gece tekrarlanırsa iltihabı dışarı atar. İltihap atıldıktan sonra kullanılmaya devam edilirse eti yakma özelliği bulunmaktadır (KK-10). Mideye ve iç organlardaki iltihaplara iyi gelir. Açık dış yaraların üstüne bırakılarak mikrop kapmasını engeller ve iyileşmeyi hızlandırır (KK-8; KK-9; KK-12; KK-13). Bu otun uzun süre deri ile temasının devam etmesi derinin yanmasına yol açtığından süreye dikkat edilmelidir (KK-6-13).

Piltan: Nazar için kullanılır (KK-11). Evin ve eşyaların güzel kokması için evin bir duvarına da asılır (KK-12). Kaynatılıp suyu başa sürülürse, saç dökülmesini azaltmaktadır (KK-3; KK-4; ).

Pingî: Bitkinin çiçekleri kurutulduktan sonra çayı içilirse soğuk algınlığına iyi gelmektedir (KK-10).

Pung (Yarpuz): i̇ç organlardaki iltihabı kurutmaya iyi gelir. Ayrıca kistlere de iyi gelmektedir (KK-2; KK-10). Akciğere yararlı olup nefes darlığı çekenler için nefes açıcı özelliği vardır (KK-3; KK4; KK-8; KK-9). Yoğurda karıştırılarak yenildiğinde, ağrı kesici özelliğe sahiptir (KK-11). Dişlerin temizlenmesinde de kullanılır (KK-8; KK-9). Taze olarak salatalarda veya kurutularak yemeklerde tüketilirse, mideyi dinlendirip, nefesi de açmaktadır (KK-13; KK-14).

Qanok (Karakavuk): Qanokun dalından elde edilen bir çeşit sakız olup, mide ağrılarına iyi gelmektedir (KK-8; KK-9). Elde edilen sakızın çiğnenmesinin ağız ve gırtlağı temizleyici işlevi bulunmaktadır. (KK-14). 
Ribes (Işkın): Şeker hastalığına, mide ağrılarına, mide kanserine yararı bir bitkidir (KK-2; KK10; KK-11). Baş ağrısına iyi gelen ribes, şeker hastalarınca çokça tüketilmektedir (KK-8; KK-9). Genel olarak tüm iç hastalıklarında şifadır (KK-1).

Muş'ta ışkın ismiyle ilgili bir efsane anlatılmaktadır. Bir kadın Kurtik dağına çıkar, sırtında da ağır bir yük vardır. Dağa tırmanırken yorulur ve bir taşın üzerine oturur. Tam dinlenecekken aniden şiddetli bir rüzgâr başlar. Annesinden kendisine yadigâr kalmış, karın bölgesine takılan ışkın uçar ve bir bitkinin dalına takılır. Kız bitkiye "Sen benim en önemli ışıınımı kurtardın bundan sonra senin adın ışkındır." der. Bitkinin tadına bakar ve hoşuna gider. Evdeki çocuklar için de toplar ve götürür. O zamandan beri herkes ışkın yemektedir. İsmi de "ışkın" olarak kalır. ${ }^{23}$

Sıpidank-Serbışk (Tükürük otu): Kaynatılıp suyu içilirse, iç hastalıklara iyi gelir. Karın sancılarını da yatıştırmaktadır (KK-2). Yeni doğum yapmış kadınlara suyu içirilip, otun kendisi de yedirilirse, karın ağrılarını azaltır (KK-11). Şeker hastalığına yararlı bir bitki olup, aynı zamanda vücut şişkinliğini de indirir (KK14).

Silmask: Tansiyonu dengeleyici özelliği vardır (KK-10).

Sipînk (Yemlik): Vücuttaki kirli kanı ve hastalıkları temizler (KK-6; KK-7). Hazmı kolaylaştırmak için yemekten önce yenilir (KK-8; KK-9).

Sîrim (Yayla sarımsağı): Kalp hastalıklarına iyi gelmektedir (KK-3; KK-5). Tazeyken yenilirse bağırsakları temizler (KK-11). Saçın dökülmesini engeller (KK-6; KK-7). Taze yenilmesi durumunda tansiyonu dengelemktedir (KK-14). illtihap kurutucu özelliğinden dolayı çiğ tüketilirse yararlıdır (KK-13).

Soryaz (Doğu soğanı): Kaynatılıp suyu içirilirse soğuk algınlığı için yararı bulunmaktadır (KK-14).

Sus (Meyan otu): İç hastalıklara iyi gelir. Yapraklarının iyice kaynatılmasıyla elde edilen şurubu öksürüğe iyi gelmektedir (KK-2).Kökü iyice kaynatılıp suyu içilirse, mide rahatsızlıklarına da yararlıdır (KK-1). Kökünün şurubu [meyan kökü] içilirse, kilo aldırır (KK-4; KK-5). Yaprakları da diş ağrıları için iyidir (KK-10).

Şelepuk (Papatya): Sivilce ve guatra iyi gelmektedir (KK-3; KK-4; KK-5). Çayı akciğere yararlı ve nefes açma özelliği vardır (KK-11).

Şîlan (Kuşburnu): Soğuk algınlığına iyi gelmektedir. Kan temizleme özelliği de vardır (KK-3; KK-5; KK-10). Meyveleri kaynatıldıktan sonra suyu astım ve bronşite iyi gelmektedir. Zayıflamak için de suyu içilir. Ayrıca yeni doğum yapan kadınlara da ağrıları dinsin diye içirilir (KK-2). Soğuk algınlığı başta olmak üzere boğaz ağrılarının tamamına iyi gelmektedir (KK-8; KK-9; KK-12). Çayı kalp ve damar hastalıklarına yararlıdır (KK-13).

Tantur: Kaynatılıp suyu içilirse bağırsak temizliğinde yararıdır (KK-8; KK-9).

Tirşok (Kuzukulağı): Genel olarak çok yararlı bir bitkidir. Vücuttaki her türlü mikrobu dışarı atar (KK-11). Guatr ve şeker hastalığına iyi geldiğine inanılmaktadır (KK-4; KK-5; KK-6; KK-7). Çiğ ve taze yenilirse, ishale iyi gelmektedir (KK-8; KK-9). Aç karınla ve çiğ olarak yenilirse bağırsak kurtlarını düşürmektedir (KK-1).

Tivirtuşk: Lohusa kadınların ağrıların dindirilmesinde ve aybaşı olan kadınlar tüketirse yararlıdır (KK-13).

Tolik (Ebegümeci): Hamile kalmayan bayanlara kaynatılıp suyu içirilirse iyi gelir. Mideye de faydası vardır. Illtihap ve kistlerin iyileşmesinde de oldukça yararlı bir bitkidir (KK-2). Çocuğu olmayan kadınların hamile kalması için bu ot iyice pişirilir, otu sıcakken bir bezin içinde kadının karnı üzerinde bekletilir. Bu işlem en az üç gece tekrar edilir. Bu işlemin karın bölgesini yumuşatıcı, karın bölgesini temizleyici ve gebeliği kolaylaştırıcı etkisi bulunur (KK-6; KK-7; KK-10). Bu ot karnı şiş olan bebekler için de kullanılmaktadır. Pişirilen ot, unla yoğrulduktan sonra hazırlanan karışım, bebeğin karnın üstüne konulur (KK-8; KK-9). Ayrıca 
gaz giderici özelliği de vardır (KK-10). Genel olarak bütün kadın hastalıklarında etkilidir. Ayrıca idrar yollarının temizlenmesi için hem yemeği hem de suyu yararlıdır (KK-13).

Xuşîr-Xaleşîrk (süt otu-sütlüce): Otun özsuyu (sütü) içeceğe bir-iki damla bırakılırsa, kabızlığı giderici özelliği vardır (KK-1). Otun özsuyunu hemoroit hastaları da kullanmaktadır. Özsu hemroidli bölgeye sürülerek tedavi edilmeye çalışılır (KK-12).

Tabloda yer vermediğimiz ancak halk hekimliğinde hangi amaçla kullanıldığı açıklanan encuz, gumus, malivaş, pıngi, sılmok, tantur, tivirtuşk gibi bitkilerin Türkçe isimleri tespit edilememiştir.

\section{TARTIŞMA}

Muş ve çevresinde halk hekimliğinin günümüzde oldukça yaygın olduğu yapılan bu alan araştırması sonucunda tespit edilmiştir. Çalışmamızın esasını oluşturan yabani bitkilerin kullanımı tespit edilirken, yabani bitkilerin sadece halk hekimliği uygulamalarında değil, beslenmede ve aynı zamanda toplanıp pazara sunulmasının aile ekonomisine de önemli katkılar sağladığı anlaşımıştır.

Muş'ta yabani bitki toplayıcılığı hem ihtiyaçların karşılanması hem de ticari amaçla yoğun bir şekilde yapılmaktadır. Özellikle ilkbaharda çevre şehirlere, hatta İstanbul, Bursa gibi uzak ve büyük şehirlere de ticaret amacıyla gönderildiği bilinmektedir. Ot toplama alışkanlığı, kırsal kesimin yanı sıra şehir merkezinde yaşayanlarda da bulunmaktadır.

Otların kullanım alanı çeşitlilik gösterebilmektedir. Bir kısmı beslenme amacıyla salamura [kereng, cağ, mendik, heliz vb.], kurutma [spink, spidark, kari vb.] ya da yeni teknolojik ürünlerden donduruculara saklanarak, sonraki yıla kadar korunarak tüketilebilmektedir. Yabani bitkilerin halk hekimliğinde kullanımı ise taze olarak, kurutularak veya kurutulduktan sonra toz haline getirilerek faydalanılmaktadır. Yabani bitkiler çay olarak, bitkinin üzerine kaynar su dökerek, haşlanarak veya kızartılarak ya da çiğ şeklinde tıbbi amaçla tedavide kullanılmaktadır. Anadolu'nun farklı bölgelerinde kullanılan yabani bitkilerin kullanım şekilleri büyük oranda örtüşmektedir. ${ }^{10,12}$

Yapılan araştırmalar sonucunda çok kısa mesafelerde dahi aynı bitkiye farklı adlar verildiği anlaşımıştır. Örneğin bitkilerden birine Muş merkezde "Garî-Karî", çevre köylerde "Karik", Varto çevresinde "Kardi" ve "kardo" ismi verilmektedir. Aynı durum hemen hemen bütün otlar için geçerlidir. Yöre insanı bitkilerin yöresel adı dışında ne Türkçe adlarını ne de yakın çevrede kullanılan diğer adları bilmektedirler. Elazığ ve Bingöl gibi çevre şehirlerde tespit edilen aynı ota birden çok ad verme Muş'ta benzer şekilde olduğu tespit edilmiştir. ${ }^{10,18}$

Çevrede çok tanınan her yerleşim yerinin halk hekimleri olmakla beraber yukarıda gösterilen yabani bitkilerle tedavi yöntemleri genel olarak halkın çoğunluğu tarafından bilinmektedir. Ancak güvenle ilaç kullanımı için tecrübeli halk hekimlerini tercih etme yoluna da gidilmektedir. Ağır hastalıkların tedavisinde bitkiler aynı olmakla beraber farklı karışımlar için halk hekimlerine başvurulmaktadır.

Muş çevresinde kullanılan bitkisel ilaçların rasyonel kullanımın yanında büyüye ve inanca dayalı kullanım şekilleri de yaygındır. Dua eşliğinde ilacın kullanımının, iyileşme üzerinde daha fazla tesir edeceği kabul edilmektedir. Türkiye'de geleneksel halk hekimliği uygulamalarında yaygın olan ocaklı kişilerin uygulamalarına olan güven Muş'ta da yaygın olduğu anlaşılmıştır. ${ }^{1,24}$

Hekimlikte kullanılan yabani bitkilerin önemli bir kısmı yetiştiği mevsime göre pazarlarda satılmaktadır. Herkesin kolaylıkla erişebildiği ve yoğun olarak bulunan otlar ise pazarlarda bulunmamaktadır. 
Halk veterinerliğinde, hayvan sağlığında ve yetiştiriciliğinde kullanılan yabani bitkilerin çoğunun ${ }^{16,18}$, halk hekimliğinde de tercih edildiği ve önemli bir kısmının da benzer rahatsızlıklar için uygulanıldığı anlaşılmaktadır.

Bitkilerle ilgili çeşitli efsanelerin (ışkın, kari, gulik vb.) oluşması, Muş kültüründe yabani bitkilerin güçlü bir şekilde yer edindiğini göstermektedir. Halkın doğaya bağımlılığı yoğun olarak devam etmektedir.

Uzakdoğu düşüncesi olan "karşıtlık" ilkesi ile 'sıcak-soğuk karşıtlığı' dengesi Muş halk hekimliğinde belirgindir. Bu ilkeye göre soğuk hastalıkları sıcak; sıcak hastalıkları ise soğuk işlemler tedavi eder. Bu ilke düşünüldüğünde Muş'un da soğuk bir iklime sahip olması soğuk havalardan kaynaklanan enfeksiyon hastalıkların yaygın olmasına yol açmıştır. Bu hastalıkların tedavi edilmesinde kurutulmuş alıç çiçeği ile kuşburnu meyvesinin kaynatılarak sıcak içilmesi bu ilkeyi doğrular niteliktedir.

Zehirli bitkilerin yol açabileceği tehlike bilinmektedir. Ancak esas önemli olan zehirli olmayan yabani bitkilerin de uzun süre veya yanlış kullanımının sağlığın bozulması açısından riski bulunduğundan bilinçli bir şekilde kullanılmasıdır.

Yazılı bir kaynağa dayanmayan ve tamamen tecrübe yoluyla elde edilen yöntemlerden oluştuğundan her bölgede hatta her uygulayıcıda aynı aynı ot farklı hastalıkların tedavisinde kullanılabilmektedir., 1,2,10,12,18 Kaynak kişiler aynı otu farklı hastalıklar için kullanabilmektedir. Örneğin tırşok (kuzukulağı), kaynak kişilerden biri tarafından guatr, bir diğeri tarafından ise mide ağrıları için kullanımının yararlı olacağını ifade eder. Bu durum diğer tüm otlarda da benzerdir.

Sonuç olarak, Muş'ta halk hekimliğinde kullanılan yabani bitkilerin adlandırmalarında farklııklar olmasına rağmen çalışma kapsamında elde edilen sonuçlar, hastalıklara yaklaşımları ve bitkisel em uygulama biçimleri Türkiye'nin diğer bölgeleriyle büyük oranda benzerlikler taşıdığı görülmüştür.

Yukarıda da açıklandığı üzere gösterilen bitkilerin dışında sadece halk hekimlerinin bildiği ve meslek sırrı olduğu gerekçesiyle paylaşıımayan bitki adlarının varlığı da söz konusudur. Bunların tamamının tespiti için farklı disiplinlerden araştırmacıların bir araya gelerek, yapacakları ortak projelerle hem kültürel hem tıbbi hem de etnobotanik yönlerinin tespit edilmesi gerekmektedir. Yörede halk hekimliğinde kullanılan bitkiler başta olmak üzere, yörede yetişmesine rağmen yeterince bilinmeyen diğer bitkilerin de sağlam bir envanteri çıkarılarak kayıt altına alınması önerilir.

\section{KAYNAKLAR}

1. Çolak F. Yazılı ve Sözlü Belgeler Işığında Niğde Halk Hekimliği. Konya: Kömen Yayınları; 2015.

2. Çopuroğlu C. İnsan-Çevre-Kültür İlişkisi Çerçevesine Fırat Havzasında Halk Hekimliği. İstanbul Üniversitesi Sosyoloji Konferansları Dergisi 2003; S.27: 15-39.

3. Çubukçu B, Özhatay N. Anadolu Halk İlaçları Üzerinde Araştırmalar-lı. Türk Halk Hekimliği Sempozyumu Bildirileri Kitabı. Ankara: Kültür Bakanlığı Milli Folklor Araştırma Dairesi Yayınları; 1989.

4. Boratav PN. 100 Soruda Türk Folkloru. Ankara: Bilgesu Yayınları; 2013.

5. Sever M. Türk Halk İnançlarında Ve Halk Hekimliği Uygulamalarında Meyve. 2004; Tubar. S. Xvı, Güz: 95-108.

6. Acıpayamlı O. Türkiye Folklorunda Halk Hekimliği Ve Özellikleri. Dtcf Dergisi 1969; S. Xxvı: 1-9.

7. Resmi Gazete, Geleneksel Ve Tamamlayıcı Tıp Uygulamaları Yönetmeliği (27 Ekim 2014) http://www.resmigazete.gov.tr/eskiler/2014/10/20141027-3.htm (Erişim tarihi: 03.12.2018)

8. Özkan TS. Folklorun Yüz Yılında Halk Hekimliği Çalışmalarına Bir Bakış. Milli Folklor 2013; 25(99):137-144.

9. Yıldırımlı Ş. Etnobotanik Ve Türk Etnobotaniği. Kebikeç İnsan Bilimleri İçin Kaynak Araştırmaları Dergisi 2004;17:175-193.

10. Polat R, et al. Bingöl Semt Pazarlarında Satılan Bitkilerin Etnobotanik Açıdan İncelenmesi. Biological Diversty And Conservation. 2012;5(3):155-161. 
11. Şar S. Anadolu'da Rastlanan Halk Hekimliği Uygulamalarına Genel Bir Bakış. Türkiye Klinikleri Tıp Etiği-Hukuku-Tarihi Dergisi 2005;13(2): 163-1178.

12. Baytop T. Türkiye'de Bitkilerle Tedavi. İstanbul: İstanbul Üniversitesi Yayınları; 1984.

13. Elmacı N. Sağlık Antropolojisi: Diyarbakır Örnekleri. Ankara: Siyasal Kitabevi; 2013.

14. Kaplan, M. Sağlık Ve Kültür'ün Buluştuğu Alan: Tıbbi Antropoloji. Folklor/Edebiyat. 2010;16(64):225-235.

15. Yoder D. Halk Tıbbı Ve Modern Tıp. Halkbiliminde Kuramlar Ve Yaklaşımlar 3. Çev. Sibel Yoğurtçuoğlu-Ayfer Gülüm, Ankara: Geleneksel Yayıncılık; 2009.

16. Ersoy R. Modernizm-Postmodernizm Bağlamında Geleneksel Tıp Uygulamalarının Güncelliği Üzerin Bir Değerlendirme. Milli Folklor 2014;26(101): 182-192.

17. Baytop T. Türkiye'nin Tıbbi Ve Zehirli Bitkileri. İstanbul: İstanbul Üniversitesi Yayınları: 1963.

18. Özen R, Doğan G. Elazığ Yöresi Veteriner Hekimliği Folklorunda Kullanılan Bitkisel illaç Hammaddeleri. Mersin Üniversitesi Lokman Hekim Tıp Tarihi Ve Folklorik Tıp Dergisi 2017;7(3):166-177.

19. Fırat M. Ferhenga Navên Riwekên Bi Kurdî. Van: Sitav Yayınları; 2013.

20. Öncül K. Kars Örnekleminde Halk Hekimliğinin Arkaik Unsurları. International Periodical For The Languages, Literature And History Of Turkish Or Turkic 2013;8(1):2031-2035.

21. Kasımoğlu A. Ferhanga Navên Nebatan A Kurdî/Kürtçe Bitki Adları Sözlüğü. İstanbul: Mardin Artuklu Üniversitesi: 2013.

22. Http://www.Hurriyet.Com.Tr/Gundem/Ayni-Koydeki-84-ikizin-Sirri-ikiz-Iksiri-Olarak-Aniliyor-40850047

23. Yel Z. Muş Gastronomisi, Muş Alparslan Üniversitesi, Fen Edebiyat Fakültesi, Türk Dili Ve Edebiyatı Bölümü, Lisans Bitirme Tezi. Muş: 2018.

24. Duvarcı A. Halk Hekimliğinde Ocaklar. Milli Folklor. 1990; S. 7: 34-38. 